\title{
Introduction: Fighting Against Illicit Tobacco Trade in the Era of Fast Change
}

\author{
Celina Nowak
}

\author{
Contents \\ 1 National Criminal Policy as a Part of Tobacco Control Policy: Justification

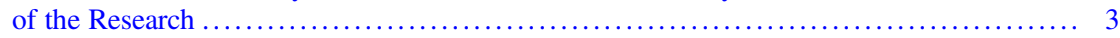 \\ 2 Scope of the Book, Methodological and Terminological Considerations ............... 6 \\ 3 Research Questions, Structure and Content of the Study $\ldots \ldots \ldots \ldots \ldots \ldots \ldots \ldots \ldots \ldots \ldots . \ldots$

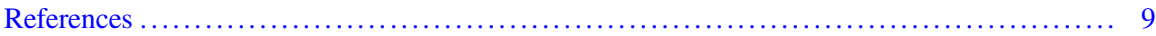

\begin{abstract}
This chapter outlines the framework of the research presented in this volume. It starts with a notion that national criminal policies on illicit tobacco trade are a part of the national tobacco control policy, and at the same time a part of a general national criminal policy and points to the need for an in-depth research of national criminal laws in this regard. It presents the scope of the research, which consists in a comparative analysis about the illicit tobacco trade and about efforts to counteract that trade in six EU Member States-four post-communist states (Lithuania, Poland, Slovakia and Romania), on the Eastern border of the Union and two “old” EU Member States (Germany, Italy).
\end{abstract}

\section{National Criminal Policy as a Part of Tobacco Control Policy: Justification of the Research}

Tobacco is the name commonly used to represent some plants in the Nicotiana genus, as well as products made with leaves of the tobacco plants. The latter is a substance that is hazardous for human health.

\footnotetext{
C. Nowak $(\square)$

Institute of Law Studies, Polish Academy of Sciences, Warsaw, Poland

e-mail: cnowak@inp.pan.pl 
Tobacco has been with mankind for millennia. Yet, its expansion as a trade item for personal use dates to the sixteenth century and the arrival of the Europeans to the Americas. In the twentieth century, scientists concluded that tobacco use is detrimental to the health of its users. Tobacco has been identified by the World Health Organisation (WHO) as one of the four major risk factors that contribute to the development of non-communicable diseases. Tobacco "accounts for over 7.2 million deaths every year (including from the effects of exposure to second-hand smoke)". ${ }^{1}$ The recent global rise of deaths attributed to non-communicable diseases has motivated international organisations to take action to prevent and control the risk factors. ${ }^{2}$ Controlling the production and controlling the use of tobacco have been significant parts of this process.

The relationship between tobacco and individual country policies are complex. On the one hand, states are socially and politically committed to the reduction of tobacco use. On the other hand, states benefit financially from tax revenue from the manufacture and sales of tobacco products. From this perspective, the relationships states have with tobacco are like their relationships with alcohol. Although the use of alcohol and tobacco constitute health hazards, they remain legal, unlike narcotic substances. As von Lampe justly states, "cigarettes are essentially a legal good". 3 However, states are committed to fighting against revenue loss from the manufacture and sale of tobacco products. The manufacture and trade of cigarettes are legal, provided these processes conform to the cigarette taxation rules adopted by states. Cigarette trade is illegal when manufacturers and sellers evade cigarette taxes.

National policies on the tobacco trade struggle to balance states' fiscal interests with their responsibility to protect public health. This balance is mainly struck by pricing tobacco products at high rates. As stated in Article 6.1 of the WHO FCTC, price and tax measures are effective means of reducing tobacco consumption by various segments of the population, young people, in particular. Therefore, tobacco products are legal but taxable with the Value Added Tax (VAT) and excise taxes. Moreover, the EU Member States are obligated to apply the European minimum rates of the excise duty. ${ }^{4}$ This application is uniform because, as mentioned in the preamble to the 2011 Directive, "the level of taxation is a major factor in the price of tobacco products, which in turn influences consumers' smoking habits. Fraud and smuggling undermine tax induced price levels and thus jeopardise the achievement of tobacco control and health protection objectives".

\footnotetext{
${ }^{1}$ A quote from “GBD 2015 Risk Factors Collaborators (2016), pp. 1659-1724”. See https://www. who.int/news-room/fact-sheets/detail/noncommunicable-diseases.

${ }^{2}$ Cf. Resolution adopted on 24 January 2012 by the General Assembly No 66/2. Political Declaration of the High-level Meeting of the General Assembly on the Prevention and Control of Non-communicable Diseases with Annex: Political Declaration of the High-level Meeting of the General Assembly on the Prevention and Control of Non-communicable Diseases.

${ }^{3}$ von Lampe (2011), p. 148.

${ }^{4}$ Cf. the Council Directive 2011/64/EU of 21 June 2011 on the structure and rates of excise duty applied to manufactured tobacco, OJ 5.7.2011, L 176/24.
} 
Despite the relatively uniform application of fiscal policies across the European Union, tobacco products prices vary significantly within and among EU Member States and non-EU Member States. The price difference of a package of cigarettes in the East of the Union may be up to four times lower than in the UK. ${ }^{5}$ These price differences encourage the illicit trade of tobacco products in the EU.

Tobacco control policies are a field of a complex dynamics, where governments are under pressure coming from different stakeholders, such as health experts, tobacco industry, NGOs. ${ }^{6}$ A tobacco control policy encompasses a variety of measures, as defined in Art. 1(d) of the 2003 WHO Framework Convention on Tobacco Control (FCTC). ${ }^{7}$ They cover reduction of the demand of tobacco as well as reduction of the supply of tobacco. In the systematics offered by the FCTC, illicit trade control, ${ }^{8}$ which is the focus of this volume, is one of the measures relating to the reduction of the supply.

By one estimate, the EU illicit tobacco trade decreases taxes significantly. ${ }^{9}$ It is also likely that illegal tobacco products, manufactured with materials of unknown origin, may be more harmful to consumers' health than legal products; although, interestingly, the content of the legal tobacco products are not verified by national authorities.

States adopt diverse policies to govern the illicit tobacco trade, which is simultaneously recognised a fiscal irregularity and a problem of criminal nature, ${ }^{10}$ and as such it is dealt with both by fiscal and criminal policy. ${ }^{11}$ Criminal policymaking should however be particularly mindful of the ultima ratio, as criminal sanctions are the most powerful tools to address social nuisances. Criminal policy choices should also take into account a variety of social, political, economic and cultural factors as they inherently influence complex and sensitive social relations.

\footnotetext{
${ }^{5}$ See detailed information on pricing policies in different states published in the annual WHO reports on tobacco. Most recent report is "WHO report on the global tobacco epidemic 2019", available at: https://www.who.int/tobacco/global_report/en/.

${ }^{6}$ See an interesting recent study on national tobacco policy by Willemsen (2018).

${ }^{7}$ Pursuant to this provision, 'tobacco control' means a range of supply, demand and harm reduction strategies that aim to improve the health of a population by eliminating or reducing their consumption of tobacco products and exposure to tobacco smoke.

${ }^{8}$ Following the wording of Art. 1(a) of the FCTC, illicit trade is to be understood as any practice or conduct prohibited by law and which relates to production, shipment, receipt, possession, distribution, sale or purchase including any practice or conduct intended to facilitate such activity.

${ }^{9}$ The black market for cigarettes in the EU is estimated to have deprived governments of EUR 10 billion in tax revenues in 2017. See KMPG Project Sun. A study of the illicit cigarette market in the European Union, Norway and Switzerland. 2017 Results, https://home.kpmg/uk/en/home/ insights/2018/07/project-sun-2017.html.

${ }^{10} \mathrm{M}$. Tonry points out to six "public policy approaches ... available for dealing with crime". They are criminal law enforcement, prevention, harm reduction, regulation, decriminalization, and nonintervention. See Tonry (2011), p. 7.

${ }^{11}$ For M. Delmas-Marty, criminal policy is a set of measures by way of which the social corps organizes responses to the phenomenon of crime. See Delmas-Marty (1992), p. 13.
} 
The national criminal policies on illicit tobacco trade, analyzed in this volume, are just a small part of the national tobacco control policy. At the same time though the criminal policy with regard to illicit tobacco trade is a part of a general national criminal policy and has to correspond and match the goals and specificities thereof. The challenges related to the creation and enforcement of the national criminal policy on illicit tobacco stem from this very double adherence.

The fight against the illicit tobacco trade has become more important in recent years, as this trade has become of increasing interest to organised crime groups. Traditionally, organised crime groups have been involved in a variety of illegal activities, often of a violent nature, such as human trafficking, drugs and extortion. However, in recent years they shifted their interest to tobacco. The danger of being caught is lower, the target market is bigger, and sanctions are less severe than for other types of offences. Interestingly, traditional criminals seeking to diversify their activities and increase their profits, turn to tax crimes. This realization should further justify a need to undertake scientific criminal law research about the illicit tobacco trade.

\section{Scope of the Book, Methodological and Terminological Considerations}

This research presents the results of comparative analysis about the illicit tobacco trade and about efforts to counteract that trade in six EU Member States. Researchers chose four states (Lithuania, Poland, Slovakia and Romania), based on their geographical location on the Eastern border of the Union. Coincidently, these four states are all post-communist countries, and their penal systems are still coping with the Soviet heritage. Researchers also chose two "old" EU Member States (Germany, Italy) that have struggled with the illicit tobacco trade.

The starting point of the research was the presumption that on the national level, even though the illicit tobacco trade constitutes both a tax irregularity and a criminal offence, the fight against the illicit trade of tobacco products is primarily conducted through the enforcement of criminal law, rather than through tax law. The tax law and criminal law have become more intertwined over recent years, ${ }^{12}$ but still, national policymakers evidently consider criminal measures to be more effective in tackling this phenomenon. Therefore, the focus of the research was domestic criminal law - the researchers examined substantive criminal law and procedural criminal law in the study countries. Administrative law (fiscal and tax law) was examined only on subsidiary basis, where necessary to complement the picture of national repressive legal framework. A secondary aim of the research was to assess the enforcement of criminal law measures and, to this end, examine the scope of the illicit tobacco trade and its prosecution in the study countries through a

\footnotetext{
${ }^{12}$ As confirmed in Alldridge (2017), p. 1 ff.
} 
comprehensive analysis of criminological data. Moreover, since criminal law constitutes an ultimate measure, the research had to control for, where possible, cooperative agreements and practices at transnational and national levels and for administrative instruments adopted by states to prevent and eliminate the illicit tobacco trade.

Studies on illicit tobacco trade published to date ${ }^{13}$ has focused to a great extent on criminological and interdisciplinary aspects of this phenomenon and its regulation. The novelty of the research presented in this volume lies in conducting analysis of "hard" criminal legislation in the study countries. Here, the illicit tobacco trade is examined from the perspective of criminal policy—criminalisation, sanctions and enforcement are all examined in detail.

A second novel element of the research at hand lies in a systematic analysis of criminal policies in Central and East European countries which have never been presented in such a comprehensive manner in international publications. The countries chosen for this research - Lithuania, Poland, Slovakia and Romania, located on and responsible for almost all the East border of the EU, with specific geographical and social circumstances, struggling with post-Soviet legacy and mentalities, and often with lack of appropriate financial and human resources, faced with the obligation to implement strict EU rules whereas their neighbouring non-EU countries have more lax policies on tobacco, are at the first line of the fight against illicit tobacco trade in the EU and therefore they deserve more attention.

As a background of the study researchers applied the 2003 WHO Framework Convention on Tobacco Control (FCTC), which had been signed by all six countries covered by this research, and the September 2018 Protocol to Eliminate Illicit Trade in Tobacco Products, signed by half of the examined countries; they also analysed issues related to the European Union response to the illicit tobacco trade.

The research group have analysed national criminal law by reviewing the existing enforcement mechanisms. The research team applied methods traditionally used for comparative legal research - they analysed the national legislation and experiences and challenges related to the fight against the illicit tobacco trade based on the results of a comprehensive and detailed questionnaire. The analysis followed the same structure, which has been subsequently reflected in the chapters on national challenges, and covered all aspects of the fight against illicit tobacco trade and tobacco-related crimes, namely criminalization, administrative regulation, preventive measures and cooperation inside the country and with external partners. National experts wrote the chapters that refer to their states' national policies and practices, also after having consulted legal practitioners and law enforcement officials in the field in their respective countries.

The data and analyses are important for national criminal policy options and best practices in the fight against the illicit tobacco trade. Findings based on the data allowed the researchers to formulate criminal law recommendations for national legislatures and international organisations, which may lead to adoption of new

\footnotetext{
${ }^{13}$ See e.g. Savona et al. (2017).
} 
mechanisms to effectively combat the illicit tobacco trade. Those recommendations are presented in the final chapter of this collection.

Concerning terminology, one note must be made at the outset of the study. Pursuant to Art. 1(f) of the WHO FCTC, "tobacco products" mean products entirely or partly made of the leaf tobacco as raw material which are manufactured to be used for smoking, sucking, chewing or snuffing. However, in this book the term "tobacco products" and "tobacco" when used in the phase "illicit tobacco trade" are treated as synonyms and will be used to cover traditional types of products manufactured from tobacco, such as cigarettes and fine-cut tobacco, as mainly these two tobacco-made products are subject of illegal trade. It should be mentioned that the research focused on traditional tobacco products, as essentially they are the object of illicit tobacco trade, and issues related to new products, in particular e-cigarettes, have not been addressed.

The research team included researchers from the field of criminal law and criminal procedure. Since a tobacco company funded the research, researchers sought approval for the research plan from the Institute of Law Studies of the Polish Academy of Sciences' Ethical Committee. Only once the Committee approved the plan, we have launched the research. We were also free to draw any conclusions we deemed pertinent for the research.

The negative impact of tobacco products on human health is indisputable. As researchers in the field of criminal law, we focused our research on states' (criminal) tobacco policies, which constitute at the same time an important part of national criminal policies and a part of the national tobacco control policy. The clear health hazards related to tobacco were not subject of this research and are very competently covered by researchers in other disciplines of sciences, in their publications.

\section{Research Questions, Structure and Content of the Study}

This edited volume constitutes an attempt to address the following research question-how examined countries construct their criminal policies with regard to illicit trade of tobacco products. Additional research questions refer to the characteristics of the national criminal policies and their effectiveness. The researchers aimed at studying what types of behaviours are covered by national law and how they are investigated, prosecuted and sanctioned.

The volume has been divided into three parts. The first one includes a chapter by Celina Nowak devoted to the presentation of the legal framework in international and EU law referring to the fight against illicit tobacco trade. This part constitutes an analysis of a legal background against which the authors of the chapters included into the second part of the volume present their national criminal policies.

The second part is a vertical part of the comparative research and as such it consists of six chapters on national criminal policies with regard to illicit tobacco trade. Each chapter has been elaborated by experts coming from respective examined legal systems. They all address penal, criminological, as well as administrative and 
social aspects of the fight against illicit trade of tobacco products in the examined country. Some chapters are more detailed (chapter on Germany by Marc Engelhart, chapter on Lithuania by Gintaras Švedas, and chapter on Poland by Konrad Buczkowski and Paweł Dziekański), whereas other are more condense, but they all provide an excellent insight into the national legal systems and national criminal policies with regard to illicit tobacco trade.

They also give an opportunity to appreciate the development of legal reflection and legal research on the examined issues in the respective countries-for instance the chapter on Romania is based on case-law only, as legal doctrine on illicit tobacco trade has not been well developed, whereas other chapters include academic sources as well.

The third part of the book ('Conclusions: criminal policy on illicit trade of tobacco products between Scylla of health concerns and Charybdis of fiscal interests'), authored by Konrad Buczkowski and Celina Nowak, presents results of a comparative analysis of the six legal systems examined in the second part of the book. The ambition of the authors of this chapter was not to plainly juxtapose analysed legal systems or to analyse them in detail, but to indicate some common strategies used by national policymakers as well as common tendencies of national criminal policies with regard to illicit tobacco trade, identified on the basis of a thorough analysis of the national chapters. It also points to the difficult choices faced by national criminal policymakers trying to reconcile health concerns, fiscal interests and specificities of national criminal policies.

Such a horizontal analysis allowed to formulate recommendations the implementation of which could contribute to an increase of effectiveness of the national fight against illicit tobacco trade.

Also, the comparative research does not allow to go into details with regard to specific national provisions, it only can provide an overall picture of the system and the national criminal policy. For this reason, the conclusions drawn on the basis of chapters presented in the second part of this volume also point to directions of the future research concerning national criminal policies with regard to illicit tobacco trade.

\section{References}

Alldridge P (2017) Criminal Justice and taxation. OUP

Delmas-Marty M (1992) Les grands systèmes de politique criminelle. PUF

GBD 2015 Risk Factors Collaborators (2016) Global, regional, and national comparative risk assessment of 79 behavioural, environmental and occupational, and metabolic risks or clusters of risks, 1990-2015: a systematic analysis for the Global Burden of Disease Study 2015. Lancet 388(10053):1659-1724. https://www.who.int/news-room/fact-sheets/detail/noncommunicablediseases

KMPG Project Sun (2017) A study of the illicit cigarette market in the European Union, Norway and Switzerland. 2017 Results, https://home.kpmg/uk/en/home/insights/2018/07/project-sun2017.html 
Savona EU, Kleiman MAR, Calderoni F (eds) (2017) Dual markets. Comparative approaches to regulation. Springer

Tonry M. (2011), Crime and Public Policy, in: The Oxford handbook of crime and public policy, Tonry M. (ed.), OUP

von Lampe K (2011) The Illegal Cigarettes Trade. In: Natarajan M (ed) International crime and justice. Cambridge University Press

"WHO report on the global tobacco epidemic 2019". https://www.who.int/tobacco/global_report/ en/

Willemsen MC (2018) Tobacco Control Policy in the Netherlands: between economy, public health, and ideology. Palgrave MacMillan. https://doi.org/10.1007/978-3-319-72368-6

Celina Nowak Ph.D., is Associate Professor and Head of the Institute of Law Studies of the Polish Academy of Sciences. She holds a Ph.D. and habilitation in law, as well as a postgraduate diploma of Université de Paris I - Panthéon-Sorbonne in criminal law and criminal policy in Europe. Her research refers to criminal law, with focus on international, EU and comparative criminal law. In addition, she has extensive experience as an academic teacher at the Kozminski University and the Warsaw University. Prof. Nowak has taken part in a number of comparative law projects, in the national and EU context, either as a project leader, or as a national expert. She has authored 2 monographs, edited and co-edited 10 books. She has written more than three dozen articles and chapters in Polish, English and French, published in Poland and internationally.

Open Access This chapter is licensed under the terms of the Creative Commons Attribution 4.0 International License (http://creativecommons.org/licenses/by/4.0/), which permits use, sharing, adaptation, distribution and reproduction in any medium or format, as long as you give appropriate credit to the original author(s) and the source, provide a link to the Creative Commons licence and indicate if changes were made.

The images or other third party material in this chapter are included in the chapter's Creative Commons licence, unless indicated otherwise in a credit line to the material. If material is not included in the chapter's Creative Commons licence and your intended use is not permitted by statutory regulation or exceeds the permitted use, you will need to obtain permission directly from the copyright holder.

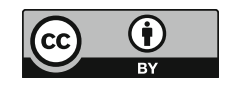

